\title{
Special issue in honor of Nicholas C. Yannelis
}

\author{
Bernard Cornet $^{1} \cdot$ M. Ali Khan ${ }^{2}$. David Levine ${ }^{3} \cdot$ Edward C. Prescott $^{4}$
}

Published online: 2 April 2021

() The Author(s), under exclusive licence to Springer-Verlag GmbH Germany, part of Springer Nature 2021

It is with great pleasure that the four authors listed above introduce the first of two parts of this special issuefor Nicholas Constantine Yannelis: they do so by introducing a scholar-activist not only to the members of the Society for Advanced Economic Theory (SAET) and to the readers of its two journals Economic Theory (ET) and Economic Theory Bulletin (ETB), but to his professional colleagues at large, of course those in economics but also in applied mathematics.

The biographical details are more or less well-known: born in Athens in 1953, obtained an undergraduate degree in economics from the Athens University of Economics and Business, earned a Master's degree at the London School of Economics and Political Science, pursued graduate studies at and the University of Rochester, and also for an year at Johns Hopkins University, and obtained his Ph.D. degree from Rochester in 1983 under the overall direction of Lionel W. McKenzie and M. Ali Khan. His first academic appointment was at the Wayne State University, with extended visiting positions at the University of Minnesota, a hiatus at Tulane University, before ending at the University of Illinois at Urbana Champaign from where he retired in 2010. He has been the "Sir Johns Hicks Professor of Economics" at the University of Manchester, and the "Henry B. Tippie Research Professor of Economics and Applied Mathematics and Computation" at the University of Iowa. He is currently "Emeritus Commerce Distinguished Alumni Professor of Economics" at the University of Illinois at Urbana-Champaign, and the "Harlan McGregor Chair in Economic Theory" at Iowa. All the names notwithstanding, it is quite a linear trajectory, all in all.

The scholarship is easy to gauge even from a cursory list of publications: the study of equilibrium concepts in games and economies with asymmetric information;

This two-part issue is based in the Summer Workshop in Economic Theory (SWET) held on October 25-27, 2018 at Université Paris I.

$\triangle \quad$ M. Ali Khan

akhan@jhu.edu

1 Department of Economics, University of Kansas, Lawrence, USA

2 Department of Economics, Johns Hopkins University, Baltimore, USA

3 Department of Economics, University of Washington at St. Louis, St. Louis, USA

4 Department of Economics, Arizona State University, Tempe, USA 
in infinite-dimensional commodity spaces; with discontinuous preferences; and the implementation of equilibria under ambiguity. A scholar is recognized by the words relied upon, and the constant use of the word equilibrium can be read as testifying to the oppositional thinking of Yannelis' mindset: the finite being turned into the infinite, the continuous into the discontinuous, the convex into the non-convex, order into non-order, completeness into incompleteness, determinateness into the ambiguous, symmetric into the asymmetric, standard into the non-standard, smooth into the nonsmooth. ${ }^{1}$ Deferring a more-comprehensive take on the research and scholarship to the introduction of the second part of this special issue, we note here that his debut in the profession, as represented by his 1983 Ph.D. dissertation, and his contemporaneous paper with Prabhakar, and the evolution and the implications of it, to take one example from what is already a 40-year oeuvre, is discussed in the first article of this issue. An article in the subsequent part of the special issue touches on

political economy rather than competitive equilibrium, [and its] analysis and results are in the spirit of Nicholas Yannelis: we do not assume particular functional forms and [draw inspiration from] two themes of Nicholas Yannelis's scientific work: the importance of fundamental results of practical importance and the insistence that they not depend upon special or arbitrary assumptions. ${ }^{2}$

It is indeed a splendid debut, one that has borne fruits manifold and diverse, and the style and signature are open to view.

We turn to the activist, and talk little less briefly of Yannelis' role in the SAET and its journals, and in the economics profession. But first, some potted history for the record. It all started in the Fall of 1986 with a conference on "Non-convexities in equilibrium and growth," jointly organized by D. J. Brown and M. Majumdar at Cornell, and in one of the conference breaks, with an extended walk in Ithaca Plantations (formally, Cornell Botanical Gardens). Roko Aliprantis and Ali Khan fanned each other's frustrations concerning what they saw as the closedness and the exclusive parochialism of economic theory journals, and kept going back to the programmatic Frisch editorial that they had then recently read. ${ }^{3}$ It was then that the idea of a new journal took root. Phone calls were made, with varying responses, to Kenneth Arrow, Robert Lucas and Edward Prescott: Mukul Majumdar and Tapan Mitra came immediately on board. A title of Annals of Economics was suggested by one of the spouses, but rejected as harking to the Annals of Mathematics, and being too presumptuous for Aliprantis. It took five years for the first issue: the obvious Managing Editor, with David Cass, Douglas Gale, Mukul Majumdar, Ed Prescott, Nick Yannelis and Yves Younes as Co-Editors, and with a novel Exposita section to be edited by Ali Khan. It was a good beginning, with Brown, Ross, Majumdar, Radner, Roth, Vande-Vate,

\footnotetext{
1 See the first paper in this issue for the importance of infinitesimal (non-standard) analysis in Yannelis' dissertation: we await his entry into non-smooth analysis.

2 See the Levine-Mattozzi paper drawing on the existence theorem on Nash equilibria, a "fundamental result that Nicholas Yannelis developed together with Pavlo Prokopovych."

3 See Ragnar Frisch (1933). Editorial. Econometrica 1:1, 1-4.
} 
Mas-Colell, Kydland, Fuhrken, Richter, Shapley and Vohra the authors of the first issue. ${ }^{4}$ The issue had the following programmatic declaration.

Modern economic techniques employ sophisticated and advanced mathematical tools in order to clarify complex economic and social problems. ET aspires to be a link in this interdisciplinary process by publishing articles of the highest quality in all areas of economics based on solid mathematical background - also high quality papers in mathematics that contribute to the advancement of economic theory. The Society for the Advancement of Economic Theory [will] advance knowledge in theoretical economics and facilitate communication among researchers in economics, mathematics, game theory, and other fields potentially useful to economics.

To say now in 2021, three decades later, that the journal and the society are enormously successful would surely be an understatement: ET is a pre-eminent theory journal and draws some of the best work in economic theory and mathematical economics. SAETsponsored conferences are heavily attended and important events in the annual calendar of the profession. Initially, however, Roko was the journal and its Society: his role was so central and his energy so great that upon his untimely death in 2009, several of us had serious concerns for the entire enterprise. And it was into this partial vacuum, and in response to the crisis, that Yannelis stepped in. He took over as Editor of ET, prevailed upon Charlie Plott and David Levine to become Presidents of the Society, and replaced an organization that was largely personal with a formal institution that could survive the death of its leader. All this he accomplished handsomely.

The SAET, an idea initially due to Prescott and with him its first President (Aliprantis Vice-President, and Yannelis Treasurer-Secretary), was based in Illinois. The Society and its Journals are now governed by an Executive Committee, with by-laws initially written by Yannelis, and with a rotating leadership. One of the important innovations, the Economic Theory Fellows, with corresponding revision of the by-laws, occurred under Levine's presidency: he (modestly) indicates that the driving forces behind this change were Nicholas and Bernard Cornet, and that he was glad to serve as their able assistant. It was then that ETB was begun, albeit with a vision of its own, but also to handle the increasing volume of high-quality work flowing into ET. The past Presidents among us have seen at close hand Nicholas' role in working behind the scenes, avoiding credit or crediting others as a member of the Executive Committee, even after he had stepped aside as President. His leadership has been instrumental for the success, and past Presidents among us can only salute with extreme gratitude all that he has done for the economics profession.

Those who know Nicholas, know well his enthusiasm and his curiosity: they can appreciate how difficult it has been for the authors to prevent his active involvement in writing these lines: how they ought to be configured, the sequence and importance of events, who and what should be cited, what to shade and what to bring into light. We have resisted this with one exception: we have submitted to his wish that this editorial introduction strictly avoid the personal and remain with the impersonal and

\footnotetext{
4 The names are listen in the order of the articles: much could be said about the articles themselves, but we simply invite the reader to look at them on his or her own.
} 
the professional, other than to mention that his passion for economics is shared with his passion for rugs and paintings. ${ }^{5}$ As to the theorists in his chosen subject, he admires Adam Smith and Léon Walras of the past, and Gerard Debreu and Wayne Shafer of his present, ${ }^{6}$ but one may perhaps give the last words to de Quincey on the cusp of the eighteenth and nineteenth centuries.

Where two ideas are correlates and antagonist forces, they explain themselves and define themselves at the same time; for the one is the rebound from the other. The reciprocal entanglement of darkness in light and light in darkness, both darkness and light are made visible, and by the two coming into collision, each exalts the other into stronger relief.

Given Nicholas' love of art and his oppositional thinking, one may also say, with HillisMiller, "The necessity of achieving an equilibrium of opposites is both a psychological and an ontological law": 'chiaroscuro' as a law of Yannelis' theoretical style. ${ }^{7}$

Publisher's Note Springer Nature remains neutral with regard to jurisdictional claims in published maps and institutional affiliations.

\footnotetext{
5 Barring his favorite Caravaggio, his specialty is eighteenth century French and British art: Romney, Gainsborough, Reynolds, Ramsay, Largilliere, Nattier, Oudry and Rigaud, perhaps in this order. For the first, see for example, Fried, 2010, The Moment of Caravaggio, Princeton University Press, Princeton; for the next two, Barrell, 1980, The Dark Side of the Landscape, Cambridge University Press, Cambridge; and for all the rest excepting Nattier, Crow, 1985, Painters and Public Life in Eighteenth-Century Paris, Yale University Press, New Haven.

6 To be sure, on reading these lines, he expressed the warmest of regards and accolades for the writers of these lines, and an invitation to each of them on a tour of his art collection with him as the guide.

7 See https://www.hetwebsite.net/het/profiles/quincey.htm, de Quincey's 1844 Logic of Political Economy, and the classic chapter on him in Hillis-Miller, 1991, The Disappearance of God, University of Illinois Press, Urbana and Chicago.
} 